\title{
APLIKASI ACTIVITY-BASED COSTING PADA UMKM
}

\author{
Oleh: \\ Himawan Pradipta \\ Universitas Ibrahimy Situbondo, Indonesia \\ dipta.ibrahimy@gmail.com
}

\begin{abstract}
:
The fact that there was a challenge for the UMKM sector was the lack of capability in terms of business menegement. One of them was accuracy in calculating the amount of the main price of production on the resulting product. even though that calculation was crucial in determining the selling price of the product. Therefore, it was important to apply a better method to make the right decision. The purpose of this study was to analyze the comparison of the calculation of the price of production using traditional costing (TC) and Activity-Based Costing (ABC) methods, as well as analyzed the advantage in gaining the application of this method. This research was a descriptive qualitative study with interview methods and documentation. The analysis showed that in the calculation of the underlying price between TC production and $\mathrm{ABC}$, there was an undercosted of $4.04 \%$, while for the profit difference there was $1.2 \%$.
\end{abstract}

Keyword: Activity-Based Costing (ABC), Traditional Costing, Harga Pokok Produksi, Laba, UMKM

\section{A. Pendahuluan}

Laba merupakan maksud utama didirikannya suatu perusahaan. Laba didapat dari kelebihan antara total pendapatan dengan total biaya. ${ }^{1}$ Pentingnya suatu perusahaan berkemampuan dalam mendapatkan laba yang maksimal, karena menjadi tolak ukur keberhasilan kinerja manajemen perusahaan di mata stakeholders. ${ }^{2}$ Guna mempertahankan dan meningkatkan posisi kompetitif, sangatlah penting bagi semua perusahaan untuk mendapatkan informasi terperinci tentang biaya. ${ }^{3}$

1 Charles T Horngren, S M Datar, and G Foster, Akuntansi Manajemen, (Jakarta: Salemba Empat, 2008), 112.

2 Ima Andriyani, Pengaruh Rasio Keuangan Terhadap Pertumbuhan Laba Pada Perusahaan Pertambangan Yang Terdaftar Di Bursa Efek Indonesia, Jurnal Manajemen Dan Bisnis Sriwijaya, 13.2 (2015), 345.

3 Dimitrios Ginoglou, Optimization Distribution of Activity Based Costing Using 
Akuntansi biaya sebagai bagian integral dari akuntansi yang dapat membantu manajemen terkait informasi biaya. Informasi ini berguna untuk perencanaan, pengambilan keputusan, pengendalian biaya serta perhitungan biaya produksi. ${ }^{4}$ Manfaatnya adalah adanya informasi mengenai perhitungan harga pokok produksi (HPPr) suatu produk yang digunakan sebagai acuan harga jual suatu produk. ${ }^{5}$ Perhitungan HPPr didapat dengan menjumlahkan seluruh unsur biaya produksi. ${ }^{6}$ Biaya yang menjadi dasar penghitungan HPPr yaitu biaya bahan baku langsung (BBB), biaya tenaga kerja langsung (BTKL), dan biaya overhead pabrik (BOP). BBB dan BTKL merupakan biaya yang dapat dengan mudah ditelusuri, sedangkan BOP diperlukan metode alokasi tertentu karena biaya ini tidak dapat diidentifikasi secara langsung pada produk. ${ }^{7}$

Metode HPPr diartikan sebagai suatu cara dalam menghitung unsur-unsur biaya yang melekat pada proses produksi. Metode untuk menentukan besaran angka HPPr terdapat beberapa macam yang dapat dilakukan namun tentunya akan memberikan dampak terhadap biaya pokok satuan unit yang diproduksi. ${ }^{8}$ Salah satu metode yang umum dipergunakan adalah menggunakan metode biaya tradisional (traditional costing/TC). Dalam metode ini, BBB dan BTKL dialokasikan langsung ke produksi, sedangkan BOP dianggap sebagai biaya langsung dengan cara menetapkan tarif overhead pabrik dimuka. ${ }^{9}$ Harga pokok per unit dari

Agent Based Technologies, European Research Studies Journal, 13.3 (2010), 195-218; Mohammad Tariq Hasan and Shammi Akter, Applications of Activity-Based Costing in Bangladesh, ASA University Review, 4.1 (2010), 40.

${ }^{4}$ R A Supriyono, Akuntansi Manajemen (Jakarta: Salemba Empat, 2011), hlm. 2.

5 Helmina Batubara, Penentuan Harga Pokok Produksi Berdasarkan Metode Full Costing Pada Pembuatan Etalase Kaca Dan Alumunium Di UD. Istana Alumunium Manado, Jurnal Emba, 1.3 (2013), 218.

${ }^{6}$ Sitty Rahmi Lasena, Analisis Penentuan Harga Pokok Produksi Pada PT. Dimembe Nyiur Agripro, Jurnal EMBA, 1.3 (2013), 586.

7 Fena Ulfa Aulia and Khairul Umam, Penerapan Activity Based Costing System Dalam Perhitungan Profitabilitas Produk Pada Ud. Niaga Bakti, IQTISHADIA: Jurnal Ekonomi \& Perbankan Syariah, 2.1 (2015), 45.

8 Dian Kusumaningtyas and Rilla Izzatul Haqqi, Activity-Based Costing System Dalam Penetapan Harga Pokok Produksi Serta Pengaruhnya Terhadap Kinerja Perusahaan (Studi Kasus Industri Kain Tenun Ikat Medali Mas Di Kota Malang), Jurnal Akuntansi \& Ekonomi FE. UN PGRI Kediri, 2.1 (2017), 37.

${ }^{9}$ Fatemeh Kowsari, Changing in Costing Models from Traditional to Performance Focused Activity Based Costing (PFABC) Activity Based Costing 2 Time Driven Activity Based Costing 3 Performance Focused Activity Based Costing, European Online Journal of Natural and Social Sciences, 2.3 (2013), 2498.

$48 \mid$ JURNAL LISAN AL-HAL 
produk yang dihasilkan adalah dengan cara total biaya yang dikeluarkan kemudian dibagi dengan jumlah unit produksi. ${ }^{10}$

Persaingan bisnis menuntut berbagai entitas perusahaan untuk memenangkan pasar. Pendekatan manajemen biaya pun mengalami reformasi dari masa ke masa. Adapun tujuannya adalah untuk memberikan suatu formula dalam menilai suatu biaya produk. Ketepatan dalam menilai biaya sebagai penentu nilai jual produk, sehingga strategi pemasaran perusahaan dapat ditentukan dengan tepat pula. Metode TC dipandang tidak bisa lagi sesuai dengan realitas perkembangan bisnis karena munculnya distorsi biaya. ${ }^{11}$ Khususnya pembebanan BOP pada perusahaan dengan produk yang heterogen. ${ }^{12}$ Akibatnya yang ditimbulkan adalah pengalokasian BOP dapat undercosted atau overcosted. Distorsi ini dapat dimusnahkan dengan cara menciptakan ulang sistem biaya menggunakan pemicu biaya aktual untuk masing- masing aktivitas. Hal inilah yang mendasari pergeseran metode TC ke Activity-Based Costing $(A B C) \cdot{ }^{13}$

Metode $A B C$ dipopulerkan sejak tahun 1980-an melalui serangkaian artikel oleh Cooper (1988, 1989) dan Cooper \& Kaplan (1989). ABC merupakan metode penetapan biaya yang dirancang memberi informasi kepada manajer dalam kaitannya untuk strategi dan keputusan yang berpotensi mempengaruhi dinamika perusahaan. ${ }^{14}$ Hirarki $A B C$ menyoroti hubungan antara aktivitas dan konsumsi sumber daya. ${ }^{15}$ Metode $A B C$ menawarkan agar pembebanan BOP didasarkan pada persentase proporsional atas aktivitas yang dilaksanakan dalam memproduksi produk. Inilah kemudian dinamakan dengan cost driver, sehingga jika

10 Dunia, Abdullah, and Sasongko, Akuntansi Biaya Edisi 4, (Jakarta: Salemba Empat, 2018), 67.

11 HT-Kaplan Johnson and Robert Kaplan, Relevance Lost, The Rise and Fall of Management Accounting, (Boston: Harvard Business School Press, 1987); John A Miller, Implementing Activity-Based Management In Daily Operations, (Wiley, 1996); Yong-Woo Kim and Glenn Ballard, Case Study-Overhead Cost Analysis, Proceedings IGLC, Gramado, Brasil, 2002, hlm. 3; Zoltan Sebestyén and Viktor Juhász, The Impact Of The Cost Of Unused Capacity On Production Planning of Flexible Manufacturing Systems, Periodica Polytechnica Social and Management Sciences, 11.2 (2003),186.

12 Ibid., 443.

13 Bastian Bustami, Akuntansi Biaya, (Jakarta: Mitra Wacana Media, 2013), 249.

14 Ibid., 41.

15 Robin Cooper and Robert S Kaplan, Measure Costs Right: Make The Right Decisions, Harvard Business Review, 66.5 (1988), hlm. 97; Robin Cooper and Robert S Kaplan, How Cost Accounting Distorts Product Costs, Strategic Finance, 69.10 (1988), hlm. 20. 
konsep ini diterapkan maka keputusan yang diambil akan lebih tepat.

Penelitian penggunaan metode $A B C$ lebih unggul dibandingkan dengan metode $T C$ telah didokumentasikan di berbagai perusahaan baik level menengah maupun atas. Misalnya penelitian Adie dan Riki (2011), yang melakukan penelitian pada perusahaan manufaktur di bidang tekstil, kemudian Mariam dan Riki (2012), dengan sampel penelitian pada perusahaan cat dan penelitian Lu, et.al (2017), yang melakukan penelitian pada sebuah perusahaan suku cadang di Cina. Namun, penelitian penerapan metode $A B C$ pada perusahaan UMKM relatif masih sedikit, pun juga pada literatur Akuntansi Biaya yang dipergunakan di kalangan mahasiswa, percontohan kasus hanya pada perusahaan berskala besar. Hal ini dirasa perlu dilakukan kajian, agar keberadaan bidang akuntansi khususnya akuntansi biaya bisa memberikan kemanfaatan bagi para pelaku usaha di segala ukuran bisnis.

Seperti kita ketahui bersama, peranan UMKM sangatlah penting dalam perekonomian masyarakat Indonesia. Hal ini dapat dicermati dari keunggulan UMKM, yaitu: (1) lebih fleksibel dan mudah beradaptasi sesuai dinamika pasar, (2) menciptakan lapangan kerja, dan (3) memiliki diversifikasi yang luas. ${ }^{16}$ Walaupun, pada kenyataannya, jika kita melihat tantangan dari UMKM sendiri sangatlah kompleks dan meliputi berbagai indikator, salah satunya ialah kurangnya kemampuan manajerial. ${ }^{17}$

Bengkel las UD. Jaya Makmur, merupakan salah satu UMKM di Kabupaten Jember yang bergerak di bidang bengkel las. Produk yang dihasilkan antara lain teralis, pagar, kanopi, rolling door, dan berbagai macam produk lainnya. Berdasarkan survey pendahuluan, dari berbagai produk yang dihasilkan, yang paling banyak dipesan oleh pelanggan adalah pemesanan pagar minimalis. Dalam perhitungan HPPr, perusahaan menggunakan metode $T C$ yang mereka pelajari secara turun temurun dari para pelaku usaha sejenis. Melihat perkembangan dunia usaha serta banyaknya kompetitor maka berdampak pula terhadap persaingan usaha yang kompetitif. Konsumen sebagai raja, menuntut perusahaan untuk membuat produk yang berkualitas, tetapi dengan harga yang terjangkau.

16 Narsa dkk., Mengungkap Kesiapan Umkm Dalam Implementasi Standar Akuntansi Keuangan Entitas Tanpa Akuntabilitas Publik ( Psak-Etap) Untuk Meningkatkan Akses Modal Perbankan, Majalah Ekonomi, (2012), 205.

17 Ida Susi Dewanti, Pemberdayaan Usaha Kecil Dan Mikro : Kendala Dan Alternatif Solusinya, Jurnal Administrasi Bisnis, 6.2 (2010), hlm. 2; Dwitya Aribawa, Pengaruh Literasi Keuangan Terhadap Kinerja Dan Keberlangsungan UMKM Di Jawa Tengah, Jurnal Siasat Bisnis, 20.1 (2016), 1-13; Betty Eliya Rokhmah and Ismail Yahya, Tantangan, Kendala , Dan Kesiapan Pemasaran, Jurnal Manajemen Zakat Dan Wakaf, 1.1 (2020), 21.

50 JURNAL LISAN AL-HAL 
Dengan demikian, dibutuhkan kemampuan manajerial dalam hal ketepatan perhitungan HPPr, jangan sampai terjadi kesalahan dalam menentukan harga jual. Penelitian ini penting dilakukan untuk menunjukkan bahwa ada metode yang lebih baik dalam perhitungan HPPr sehingga perusahaan dapat mengetahui besaran laba yang sebenarnya atas kegiatan usahanya.

\section{B. Landasan Teori}

\section{Akuntansi Biaya}

Akuntansi biaya adalah proses mencatat, menggolongkan, meringkas dan menyajikan biaya pembuatan dan penjualan produk atau jasa, dengan cara- cara tertentu, serta penafsiran terhadapnya. ${ }^{18}$ Biaya merupakan obyek dari akuntansi biaya, dimana informasi yang dihasilkan dari akuntansi biaya akan dijadikan pedoman dalam pengambilan keputusan oleh pihak internal perusahaan. Konsep akuntansi biaya diperlakukan untuk kegiatan pengklasifikasian, analisis dan pengumpulan mengenai biaya, sehingga pembahasan akuntansi biaya dapat dijadikan pedoman dalam penyusunan laporan biaya.

Dalam menjalankan fungsinya dengan baik, manajemen membutuhkan suatu informasi yang menjadikan informasi tersebut sebagai tools of management. Adapun tujuan dari informasi biaya adalah untuk (1) penentuan harga pokok, (2) perencanaan biaya, (3) pengendalian biaya, dan (4) dasar untuk pengambilan keputusan yang khusus. ${ }^{19}$

\section{Laba}

Laba didefinisikan sebagai laba operasi dikurangi pajak, bunga, riset dan pengembangan. ${ }^{20}$ Di dalam laporan laba rugi, penghasilan bersih didapat dari membandingkan pendapatan dan biaya. ${ }^{21}$ Definisi lain dari laba adalah perbedaan antara capaian pendapatan yang didapat dari transaksi perusahaan dalam kurun tertentu, dikurangi biaya yang dikeluarkan. ${ }^{22}$ Berdasarkan beberapa definisi tersebut dapat disimpulkan

18 Mulyadi, Akuntansi Biaya, (Yogyakarta: STIE, 2016), 2.

19 Ibid., 4-5.

20 Don R Hansen and Maryanne M Mowen, Managerial Accounting (Oklahoma: Thomson, South Western, 2007), 59.

21 (Halim dkk., Akuntansi Manajemen (Akuntansi Manajerial) Edisi Ke 2, (Yogyakarta: BPFE, 2013), 42.

22 Sofyan Syafri Harahap, Teori Akuntansi (Jakarta: PT RajaGrafindo Persada, \begin{tabular}{l|l} 
JURNAL LISAN AL-HAL & 51
\end{tabular} 
bahwa laba didapatkan dari selisih lebih pendapatan dikurangi seluruh biaya yang timbul setelah terjadi aktivitas transaksi barang maupun jasa. Kegiatan transaksi ini meliputi kegiatan pemesanan, proses produksi hingga barang atau jasa telah diserahkan.

Laba terdiri dari beberapa unsur antara lain: (1) pendapatan (revenue) adalah arus masuk dari penyerahan atau produksi suatu barang, pemberian jasa, atau aktivitas lain yang merupakan usaha terbesar atau usaha pertama yang sedang dilakukan entitas tersebut, (2) beban (expense) adalah arus keluar dari penyerahan atau produksi suatu barang, pemberian jasa, atau aktivitas lain yang merupakan usaha terbesar atau usaha pertama yang sedang dilakukan entitas tersebut, (3) keuntungan (gain) adalah peningkatan dalam ekuitas atau (aktiva bersih) dari transaksi yang terjadi sesekali dari suatu entitas dan dari semua transaksi, dan (4) kerugian (loss) adalah penurunan dalam ekuitas (aktiva bersih) dari transaksi yang terjadi sesekali dari suatu entitas dan dari semua transaksi. ${ }^{23}$

\section{Harga Pokok Produksi (HPPr)}

Harga pokok produksi adalah pembebanan biaya yang membantu tujuan spesifik manajerial perusahaan. Artinya penentuan HPPr bergantung pada tujuan manajerial yang ingin dicapai. Biaya-biaya yang terjadi dalam kegiatan manufaktur disebut biaya produksi (production cost or manufacturing cost). Biaya-biaya yang timbul pada proses produksi akan mempengaruhi perubahan harga pokok produksi. Baik peningkatan maupun penurunan biaya-biaya tersebut akan mempengaruhi proses penentuan HPPr. Biaya-biaya yang biasanya akan mempengaruhi proses produksi yaitu biaya bahan baku, biaya tenaga kerja dan biaya overhead pabrik. ${ }^{24}$

Klasifikasi HPPr terdapat 3 elemen yaitu (1) BBB langsung yang merupakan biaya perolehan dari seluruh bahan baku langsung yang menjadi bagian utama dari sebuah barang jadi, (2) BTKL yang merupakan gaji atau upah yang dibayarkan untuk semua tenaga kerja yang terlibat secara langsung dalam proses produksi untuk menghasilkan barang jadi, dan (3) BOP yang merupakan semua biaya untuk memproduksi suatu

2007), 31.

${ }^{23}$ Ghozali Imam and Anis Chariri, Teori Akuntansi (Semarang: Badan Penerbit Universitas Diponegoro, 2007), 38.

${ }^{24}$ Ibid., 63.

52 JURNAL LISAN AL-HAL 
produk selain BBB langsung dan BTKL. ${ }^{25}$

Penentuan HPPr digunakan untuk perhitungan laba atau rugi perusahaan. Selain itu, HPPr memiliki peranan dalam pengambilan keputusan perusahaan untuk beberapa hal seperti membuat produk baru, menghentikan atau meneruskan produk, menerima atau menolak pesanan, membeli atau membuat sendiri dan menjual langsung atau memproses lebih lanjut. Keakuratan perhitungan HPPr akan menjadi dasar bagi manajemen dalam pengambilan keputusan harga jual produknya.

\section{Traditional Costing (TC)}

Metode biaya tradisional adalah BBB, BTKL, BOP baik yang bersifat variabel maupun tetap, menjadi biaya produk. Menurut metode biaya tradisional jumlah biaya yang dikeluarkan berbanding lurus dengan besarnya jumlah unit yang diproduksi, dan untuk menghitung harga pokok per unitnya, dengan cara total biaya dibagi dengan jumlah unit yang produksinya. ${ }^{26}$

Kelebihan metode TC adalah: (1) sederhana dan mudah diterapkan, (2) memberikan laporan manajemen dengan menunjukan biaya yang dikeluarkan, dan (3) sesuai dengan PABU. ${ }^{27}$ Sedangkan kelemahan metode TC adalah (1) biaya-biaya di luar produksi yang mulai signifikan jumlahnya tidak mendapatkan perhatian yang memadai dari manajemen, (2) manajemen tidak memperoleh informasi biaya untuk pengelolaan perusahaan dan informasi tentang biaya produk yang akurat, (3) sistem pengendalian biaya seperti tidak baik untuk perusahaan yang memiliki BBB dan BTKL yang proporsinya tidak signifikan dibandingkan dengan total biaya pembuatan produk, (4) tidak dapat menunjukkan penyebab terjadinya penyimpangan biaya, dan (5) menggunakan allocation intensive dalam memperlakukan overhead pabrik sehingga cost product yang dihasilkan tidak akurat, karena dasar alokasi yang digunakan sembarang. ${ }^{28}$

\section{Activity-Based Costing (ABC)}

$A B C$ didefinisikan sebagai sistem pendekatan perhitungan biaya

25 Ghozali Imam and Anis Chariri, Teori Akuntansi (Semarang: Badan Penerbit Universitas Diponegoro, 2007), 69.

${ }^{26}$ Ibid.,157.

27 Ibid.,143.

28 William K Carter, Cost Accounting, (Cengage Learning, 1999), 94. 
yang dilakukan berdasarkan aktivitas yang ada di perusahaan. ${ }^{29}$ Dasar pemikirannya adalah penyebab timbulnya biaya disebabkan aktivitas yang dilakukan dalam suatu perusahaan, sehingga wajar jika pengalokasian biaya-biaya tidak langsung dilakukan berdasarkan penggunaan dari aktivitas tersebut. ${ }^{30}$

Penerapan sistem ABC dirancang sedemikian rupa sehingga setiap biaya yang tidak dapat dibebankan secara langsung kepada obyek biaya, dialokasikan kepada obyek biaya berdasarkan aktivitas dan biaya dari setiap aktivitas yang kemudian pada akhirnya akan dialokasikan kepada obyek biaya berdasarkan konsumsi dari masing-masing aktivitas tersebut. ${ }^{31}$ Obyek biaya adalah sesuatu yang menyebabkan biaya tersebut akan diukur, misalnya produk, pelanggan, departemen dan lainnya. Disini dapat dikatakan $A B C$ menghitung biaya produk dan membebankan biaya produk sesuai dengan obyek biayanya, berdasarkan aktivitas yang dibutuhkan untuk menghasilkan suatu barang atau jasa. ${ }^{32}$ Oleh sebab itu, penerapan $A B C$ akan mendukung proses pengambilan keputusan strategis dalam perusahaan seperti keputusan tentang harga jual suatu produk dikarenakan penerapan $A B C$ mengharuskan untuk melakukan identifikasi dan perbaikan atas seluruh kegiatan atau aktivitas yang dilakukan pada sebuah perusahaan.

Adapun manfaat dan kelemahan dari penerapan metode $A B C$. Manfaatnya adalah (1) membantu mengidentifikasi ketidakefisienan yang terjadi dalam proses produksi, baik per departemen, per produk ataupun per aktivitas, (2) membantu pengambilan keputusan dengan lebih baik karena perhitungan biaya atas suatu obyek biaya menjadi lebih akurat dan (3) membantu mengenalikan biaya utamanya biaya overhead pabrik kepada tingkatan individual dan tingkatan departemental. Sedangkan kelemahannya adalah tidak mudah untuk melakukan pembebanan biaya overhead pabrik, salah satu contohnya adalah ketika membebankan biaya keamanan pabrik kepada produk dengan dasar jumlah jam kerja tenaga kerja (pembebanan ini arbiter) dengan asumsi bahwa semakin lama proses produksi membutuhkan biaya keamanan yang semakin besar. ${ }^{33}$

Perbedaan mendasar antara $T C$ dengan $A B C$ dapat dilihat pada

${ }^{29}$ William K Carter, Cost Accounting, (Cengage Learning, 1999). 442.

30 Ibid., hlm. 144.

31 Ibid., hlm. 144.

32 Ibid., hlm. 443.

33 Ibid., hlm. 443.

54 JURNAL LISAN AL-HAL 
tabel berikut ini. ${ }^{34}$ :

/

Tabel 1. Perbedaan Traditional Costing dengan ABC Costing

\begin{tabular}{|c|c|c|}
\hline Keterangan & Traditional Costing & $A B C$ Costing \\
\hline $\begin{array}{l}\text { Penentuan harga } \\
\text { pokok produk }\end{array}$ & $\begin{array}{l}\text { menggunakan cost } \\
\text { driver lebih banyak, } \\
\text { sehingga mempunyai } \\
\text { tingkat ketelitian lebih } \\
\text { tinggi }\end{array}$ & $\begin{array}{l}\text { hanya menggunakan } \\
\text { satu atau dua cost } \\
\text { driver berdasarkan } \\
\text { unit }\end{array}$ \\
\hline $\begin{array}{l}\text { Pemacu besaran } \\
\text { overhead pabrik }\end{array}$ & $\begin{array}{l}\text { Menggunakan dasar } \\
\text { aktivitas }\end{array}$ & $\begin{array}{l}\text { Menggunakan dasar } \\
\text { satu atau dua basis } \\
\text { alokasi }\end{array}$ \\
\hline Fokusisasi & $\begin{array}{l}\text { biaya, mutu, dan faktor } \\
\text { waktu }\end{array}$ & $\begin{array}{l}\text { kinerja keuangan } \\
\text { jangka pendek }\end{array}$ \\
\hline $\begin{array}{l}\text { Pembagian } \\
\text { konsumsi } \\
\text { overhead pabrik }\end{array}$ & $\begin{array}{l}\text { Dibagi menjadi } 4 \\
\text { empat kategori yaitu: } \\
\text { unit, batch, produk, } \\
\text { dan fasilitas }\end{array}$ & $\begin{array}{l}\text { membagi biaya } \\
\text { overhead dalam unit } \\
\text { yang lain. }\end{array}$ \\
\hline
\end{tabular}

\section{Usaha Mikro Kecil Menengah (UMKM)}

Berdasarkan Undang-undang Republik Indonesia No.9 Tahun 1995 tentang Usaha Kecil dinyatakan dalam pasal 1 bahwa : "Usaha kecil adalah kegiatan ekonomi rakyat yang berskala kecil dan memenuhi kriteria kekayaan bersih atau hasil penjualan tahunan serta kepemilikan sebagaimana diatur dalam Undang-undang ini".

Menurut Pasal 5 ayat 1, kriteria usaha kecil adalah :

1. Memiliki kekayaan bersih paling banyak Rp. 200.000.000,- (dua ratus juta rupiah). Tidak termasuk tanah dan bangunan tempat usaha, atau

2. Memiliki hasil penjualan tahunan paling banyak Rp. 1.000.000.000 (satu miliar rupiah)

3. Milik Warga Negara Indonesia

4. Berdiri sendiri, bukan merupakan anak perusahaan atau cabang perusahaan yang dimiliki, dikuasai, atau berafiliasi baik langsung maupun tidak langsung denagn usaha menengah atau usaha bersama

5. Berbentuk usaha orang perseorangan, badan usaha yang tidak berbadan hukum, badan usaha yang berbadan hukum, termasuk koperasi

34 Ibid., 95. 


\section{Metode}

Penelitian ini merupakan penelitian kualitatif dengan pendekatan studi kasus. Tujuan studi kasus adalah subyek tertentu dilakukan penyelidikan secara mendalam dengan tujuan memberikan gambaran yang lengkap mengenai subyek tertentu. ${ }^{35}$ Dalam penelitian ini, populasinya adalah UMKM bengkel las di Kabupaten Jember. Sedangkan sampelnya adalah UD. Jaya Makmur yang sudah berkiprah sebagai pengusaha bengkel las $>5$ tahun. Teknik pengambilan sampel dalam penelitian ini dilakukan dengan metode random sampling. Jenis dan sumber data yang digunakan yaitu data primer dan data sekunder. Metode pengumpulan data dengan melakukan wawancara dan dokumentasi. Pengukuran yang digunakan adalah sebagai berikut:

Tabel 2. Pengukuran Komponen Biaya

\begin{tabular}{|c|c|}
\hline Komponen & Pengukuran \\
\hline Laba & Laba = harga jual produk - harga pokok produksi \\
\hline Harga & $\mathrm{HPP}=\mathrm{BB}+\mathrm{BTKL}+\mathrm{BOP}$ \\
\hline \multicolumn{2}{|l|}{ Produksi (HPPr) } \\
\hline Biaya Overhead & $T C$ \\
\hline Pabrik (BOP) & $\begin{array}{l}\text { HPPr Unit = Total Biaya : Jumlah Unit Yang } \\
\text { Diproduksi } \\
A B C\end{array}$ \\
\hline & $\begin{array}{llr}\text { Membebankan biaya overhead pada produk } \\
\text { berdasarkan banyaknya aktivitas } & \text { yang } \\
\text { dikonsumsi oleh masing-masing produk } & \end{array}$ \\
\hline
\end{tabular}

Teknik analisis data yang digunakan adalah langkah pertama yaitu melakukan dokumentasi salah satu transaksi pemesanan pagar minimalis UD. Jaya Makmur, langkah kedua yaitu melakukan perhitungan HPPr menggunakan metode biaya tradisional, langkah ketiga yaitu melakukan perhitungan HPPr menggunakan metode $A B C$ dengan tahapan sebagai berikut: tahap pertama, menentukan harga pokok berdasar aktivitas yaitu dengan menelusuri biaya dari sumber daya ke aktivitas yang mengkonsumsinya. Tahap ini terdiri dari mengidentifikasi aktivitas,

35 Nur Indriantoro and Bambang Supomo, Metodologi Penelitian Bisnis Untuk Akuntansi Dan Manajemen Edisi Pertama Cetakan Keenam, (Yogyakarta: BPFE, 2014), 125.

$56 \mid$ JURNAL LISAN AL-HAL 
menghubungkan berbagai biaya dengan berbagai aktivitas, penentuan kelompok-kelompok biaya yang homogen (homogeneous cost pool) dan menentukan cost driver berdasarkan aktivitas. Tahap kedua, merupakan pembebanan biaya overhead dari setiap kelompok aktivtas pada setiap produk, lalu menjumlahkan biaya overead yang dibebankan ke produk dari biaya kelompok aktivitas yang telah dihitung sebelumnya. Tahap ketiga, menyusun perhitungan harga pokok produksi menurut metode ABC.

Langkah keempat, yaitu membandingkan hasil perhitungan harga pokok produksi yang dihitung berdasarkan metode biaya tradisional dengan harga pokok produksi yang dihitung menggunakan metode $A B C$ kemudian menghitung selisihnya. Dan langkah kelima, melakukan analisis metode mana yang lebih tepat dalam penentuan harga pokok produksi untuk UMKM bengkel las UD. Jaya Makmur.

\section{Gambar 1. Teknik Analisis Data}

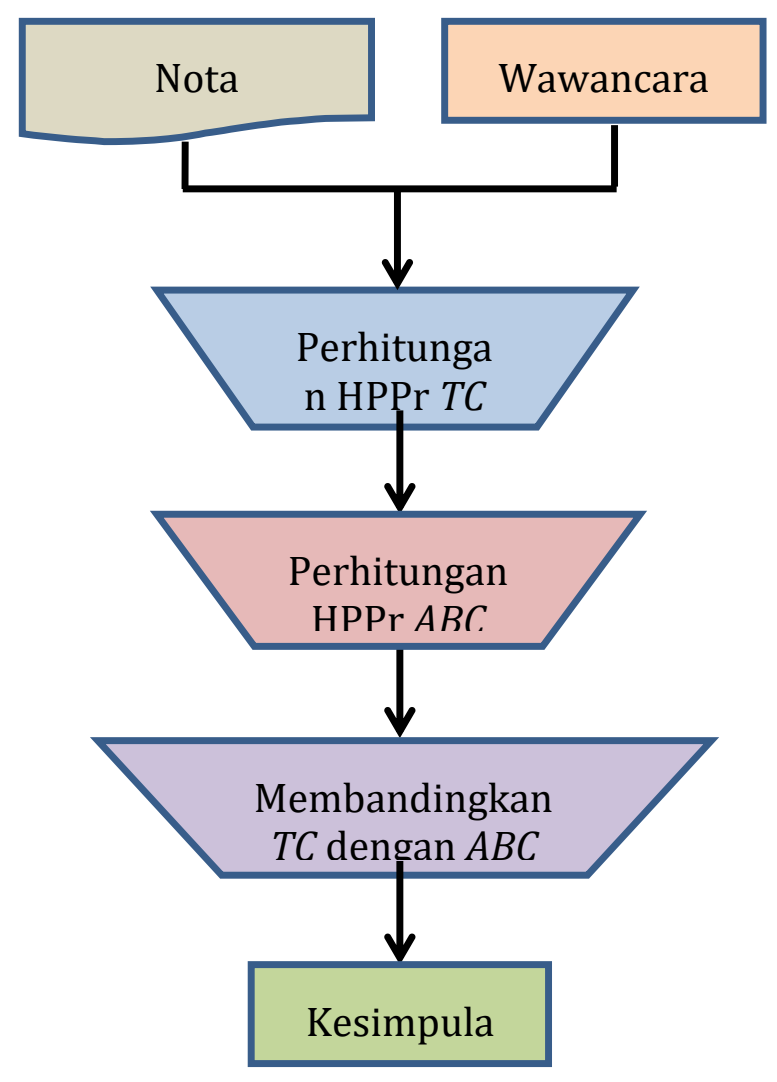




\section{Hasil dan Pembahasan}

Peneliti telah melakukan observasi dengan cara melakukan wawancara kepada pemilik UD. Jaya Makmur untuk mengetahui produk apa saja yang dibuat, harga jual, dan bagaimana perhitungan yang dilakukan serta permintaan dokumen berupa nota transaksi. Karakteristik bengkel las belum dikatakan selesai jika produk tersebut belum selesai terpasang di pelanggan sehingga yang menjadi dasar perhitungan biaya adalah biaya produksi dan biaya distribusi. Pada umumnya, pengusaha bengkel las menitikberatkan perhitungan HPPr pada tiga aspek biaya yaitu; (1) biaya bahan, (2) biaya tenaga kerja, dan (3) biaya pemasangan produk. Berikut contoh salah satu perhitungan harga pokok produksi yang dilakukan oleh UD. Jaya Makmur atas pemesanan pagar minimalis

58 JURNAL LISAN AL-HAL 
Tabel 3. Perbandingan Perhitungan Harga Pokok Produksi Traditional Costing dan Activity-Based Costing

\begin{tabular}{|c|c|c|c|c|c|}
\hline \multirow{2}{*}{$\begin{array}{l}\mathbf{N} \\
\mathbf{0}\end{array}$} & \multicolumn{2}{|c|}{ Traditional Costing } & \multicolumn{3}{|c|}{ Activity-Based Costing } \\
\hline & Keterangan & Rp. & Keterangan & & Rp. \\
\hline $\begin{array}{l}1 . \\
2 . \\
3 .\end{array}$ & $\begin{array}{l}\text { BBB } \\
\text { BTKL } \\
\text { Pemasangan: } \\
\text { Tenaga Kerja } \\
\text { BBM } \\
\text { Konsumsi }\end{array}$ & $\begin{array}{l}240.000 \\
115.000 \\
100.000\end{array}$ & 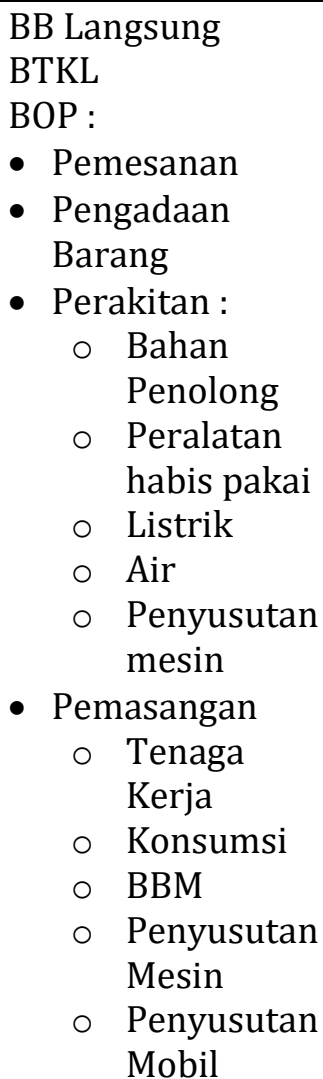 & $\begin{array}{r}20.000 \\
35.000 \\
\\
944.520 \\
121.000 \\
33.333,33 \\
6.666,66 \\
74.112,93 \\
\\
200.000 \\
100.000 \\
100.000 \\
15.244,27 \\
24.983,14\end{array}$ & $\begin{array}{r}4.611 .480 \\
800.000\end{array}$ \\
\hline & HPPr & 6.811 .000 & HPPr & & 7.086.340,33 \\
\hline & Jml Produksi & $14 \mathrm{~m} 2$ & Jml Produksi & & $14 \mathrm{~m} 2$ \\
\hline & HPPr / m2 & 486.500 & $\mathrm{HPPr} / \mathrm{m} 2$ & & $506.167,17$ \\
\hline
\end{tabular}

Sumber: laporan keuangan UD. Jaya Makmur, data diolah

Dari Tabel 3 di atas menunjukkan bahwasanya hasil perhitungan HPPr per $\mathrm{m} 2$ dengan metode $T C$ dibandingkan $A B C$, undercosted sebesar Rp. 19.667,17 (4,04\%). Hal ini dikarenakan pada metode $A B C$ telah memasukkan seluruh pemicu biaya (cost driver) menggunakan dasar aktivitas-aktivitas yang dilakukan selama proses produksi hingga pemasangan produk ke konsumen, sehingga perhitungan yang didapatkan lebih tepat dan akurat. 
Tabel 4. Perhitungan Laba

\begin{tabular}{lrrr}
\hline Metode & HPPr/m2 (Rp.) & Harga Jual/m2 (Rp.) & Laba/m2 (Rp.) \\
\hline$T C$ & 486.500 & 600.000 & 113.500 \\
$A B C$ & $506.167,17$ & 600.000 & $93.832,83$ \\
& & Selisih & $19.667,17$ \\
\hline
\end{tabular}

Dari Tabel 4 dapat ditunjukkan perhitungan laba yang didapatkan dari kedua pendekatan perhitungan HPPr. Metode $A B C$ dapat menyajikan biaya yang seharusnya dikeluarkan oleh pengusaha secara terperinci dan berapa laba sesungguhnya yang akan didapatkan per $\mathrm{m} 2$ atas pemesanan pagar minimalis. Selisih Rp. 19.667,17 merupakan perhitungan komponen biaya yang tidak dimasukkan dalam perhitungan menggunakan metode TC.

\section{E. Simpulan}

Berdasarkan hasil penelitian, dapat disimpulkan bahwa metode $A B C$ menghasilkan perhitungan yang lebih akurat dibandingkan metode traditional costing. Hal ini dibuktikan dengan hasil perhitungan HPPr per m2 untuk pemesanan pagar minimalis menggunakan metode $A B C$ lebih tinggi 4,04\% jika dibandingkan dengan metode traditional costing. Artinya jika menggunakan pendekatan metode traditional costing menyebabkan undercosted. Sedangkan dari sisi laba terdapat selisih sebesar Rp. 19.667,17. Selisih perhitungan terjadi dikarenakan pada metode traditional costing belum memasukkan beberapa objek biaya yang seharusnya diperhitungkan dalam HPPr yaitu biaya penyusutan mesin dan kendaraan. Selain hal tersebut, metode $A B C$ menyajikan pembiayaan yang lebih terperinci sehingga akan memudahkan pengusaha untuk mengambil suatu keputusan dalam pengalokasian biaya terhadap suatu produk terutama untuk penentuan harga jual yang tepat.

Implikasi penelitian bagi UD. Jaya Makmur dari penelitian ini, diharapkan menjadi bahan pertimbangan dalam menghitung HPPr, terutama untuk menghitung pekerjaan dengan volume yang cukup tinggi akan lebih baik jika dalam perhitungan HPPr menggunakan metode $A B C$. Diharapkan pula pada penelitian selanjutnya, dapat melakukan penelitian serupa kepada para pelaku UMKM di bidang selain manufaktur sebagai sarana sumbangsih pemikiran kepada manajemen atas penerapan metode tersebut dan juga turut andil dalam menaikkan kelas para pelaku UMKM dalam globalisasi dan persaingan bisnis.

$60 \mid$ JURNAL LISAN AL-HAL 


\section{DAFTAR PUSTAKA}

Andriyani, Ima, 'Pengaruh Rasio Keuangan Terhadap Pertumbuhan Laba Pada Perusahaan Pertambangan Yang Terdaftar Di Bursa Efek Indonesia', Jurnal Manajemen Dan Bisnis Sriwijaya, 13. 2. 2015.

Aribawa, Dwitya, 'Pengaruh Literasi Keuangan Terhadap Kinerja Dan Keberlangsungan UMKM Di Jawa Tengah', Jurnal Siasat Bisnis, 20.1. 2016.

Aulia, Fena Ulfa, and Khairul Umam, 'Penerapan Activity Based Costing System Dalam Perhitungan Profitabilitas Produk Pada Ud. Niaga Bakti', IQTISHADIA: Jurnal Ekonomi \& Perbankan Syariah, 2.1. 2015.

Batubara, Helmina, 'Penentuan Harga Pokok Produksi Berdasarkan Metode Full Costing Pada Pembuatan Etalase Kaca Dan Alumunium Di UD. Istana Alumunium Manado', Jurnal Emba, 1. 3. 2013.

Bustami, Bastian, Akuntansi Biaya. Jakarta: Jakarta: Mitra Wacana Media, 2013.

Carter, William K, Cost Accounting. Cengage Learning, 1999.

Cooper, Robin, and Robert S Kaplan, 'How Cost Accounting Distorts Product Costs', Strategic Finance, 69.10. 1988.

- - , 'Measure Costs Right: Make The Right Decisions', Harvard Business Review, 66.5. 1988.

Dewanti, Ida Susi, 'Pemberdayaan Usaha Kecil Dan Mikro: Kendala Dan Alternatif Solusinya', Jurnal Administrasi Bisnis, 6.2. 2010.

Dunia, Firdaus A, Wasilah Abdullah, and Catur Sasongko, Akuntansi Biaya, Edisi 4. Jakarta: Salemba Empat. 2018.

Ginoglou, Dimitrios, 'Optimization Distribution Of Activity Based Costing Using Agent Based Technologies', European Research Studies Journal, 13.3. 2010.

Halim, Abdul, Bambang Supomo, and Muhammad Syam Kusufi, Akuntansi Manajemen (Akuntansi Manajerial) Edisi Ke 2. Yogyakarta: BPFE, 2013.

Hansen, Don R, and Maryanne M Mowen, Managerial Accounting. Oklahoma: Thomson, South Western, 2007.

Harahap, Sofyan Syafri, Teori Akuntansi. Jakarta: PT RajaGrafindo Persada, 2007.

Hasan, Mohammad Tariq, and Shammi Akter, 'Applications of ActivityBased Costing in Bangladesh', ASA University Review, 4.1. 2010.

Horngren, Charles T, S M Datar, and G Foster, Akuntansi Manajemen. Jakarta: Salemba Empat, 2008.

Imam, Ghozali, and Anis Chariri, Teori Akuntansi. Semarang: Badan \begin{tabular}{l|l} 
JURNAL LISAN AL-HAL & 61
\end{tabular} 
Penerbit Universitas Diponegoro, 2007.

Indriantoro, Nur, and Bambang Supomo, Metodologi Penelitian Bisnis Untuk Akuntansi Dan Manajemen Edisi Pertama Cetakan Keenam. Yogyakarta: BPFE, 2014.

Johnson, HT-Kaplan, and Robert Kaplan, RS (1987) Relevance Lost, The Rise and Fall of Management Accounting. Boston: Harvard Business School Press, 1987.

Kim, Yong-Woo, and Glenn Ballard, 'Case Study-Overhead Cost Analysis', Proceedings IGLC, Gramado, Brasil, 2002.

Kowsari, Fatemeh, 'Changing in Costing Models from Traditional to Performance Focused Activity Based Costing (PFABC) Activity Based Costing 2 Time Driven Activity Based Costing 3 Performance Focused Activity Based Costing', European Online Journal of Natural and Social Sciences, 2.3. 2013.

Kusumaningtyas, Dian, and Rilla Izzatul Haqqi, 'Activity-Based Costing System Dalam Penetapan Harga Pokok Produksi Serta Pengaruhnya Terhadap Kinerja Perusahaan (Studi Kasus Industri Kain Tenun Ikat Medali Mas Di Kota Malang)', Jurnal Akuntansi \& Ekonomi FE. UN PGRI Kediri, 2.1. 2017.

Lasena, Sitty Rahmi, 'Analisis Penentuan Harga Pokok Produksi Pada PT. Dimembe Nyiur Agripro', Jurnal EMBA, 1.3. 2013.

Miller, John A, Implementing Activity-Based Management In Daily Operations. Wiley, 1996.

Mulyadi, Akuntansi Biaya, Akuntansi Biaya. Yogyakarta: STIE, 2016.

Narsa, I Made, Agus Widodo, and Sigit Kurnianto, 'Mengungkap Kesiapan Umkm Dalam Implementasi Standar Akuntansi Keuangan Entitas Tanpa Akuntabilitas Publik ( Psak-Etap ) Untuk Meningkatkan Akses Modal Perbankan', Majalah Ekonomi, 3, 2012.

Rokhmah, Betty Eliya, and Ismail Yahya, 'Tantangan, Kendala, Dan Kesiapan Pemasaran', Jurnal Manajemen Zakat Dan Wakaf, 1.1. 2020.

Sebestyén, Zoltan, and Viktor Juhász, 'The Impact Of The Cost Of Unused Capacity On Production Planning Of Flexible Manufacturing Systems', Periodica Polytechnica Social and Management Sciences, 11.2. 2003.

Supriyono, R A, Akuntansi Manajemen. Jakarta: Salemba Empat, 2011.

Undang-undang Republik Indonesia No.9 Tahun 1995 Tentang Usaha Kecil, 26 Desember 1995, Lembaran Negara Republik Indonesia Tahun 1995 No. 74, Jakarta

$62 \mid$ JURNAL LISAN AL-HAL 